\title{
Design of the Expert System for Edamame Grading Using Forward Chaining Method
}

\author{
Yuli Wibowo $^{1^{*},}$, Nidya Shara Mahardika ${ }^{2}$, Ruhul Afrizal ${ }^{3}$, I Gusti Bagus Udayana ${ }^{4}$ \\ 1,2,3 Department of Agro-industrial Technology, Faculty of Agricultural Technology Jember University, \\ Indonesia \\ ${ }^{4}$ Faculty of Agricultural, Warmadewa University, Indonesia \\ *Email: yuliwibowo.ftp@unej.ac.id
}

\begin{abstract}
Edamame grade is determined based on edamame quality parameters with several parameters that are quite a lot. The process of deciding edamame grade is relatively complicated and challenging. To determine the edamame grade, an experienced expert in the field is needed. With limited grading experts, the design of expert systems for grading edamame can help users or companies to determine edamame grade. This study aims to design an expert system for determining edamame grade, which can determine the quality of edamame accurately. The Design of an expert system in this research uses the forward chaining method. The stages of designing an expert system include problem identification, knowledge acquisition, building a data flow diagram, compile the database, building a decision tree diagram, and developing a user interface. The results showed that the expert system has been verified and validated well. Verification test results show that all the menu buttons on the expert system application are functioning correctly. Then, the validation results also show that the edamame quality output produced by the expert system is compatible with the expert solution, meaning that the expert system's output data is by following with the results of the decision given by the expert. In testing the validation of determining the quality is appropriate. The results of the verification and validation of the edamame grading expert system show that the expert system has produced satisfactory outcomes. Expert system output is compatible with the solution provided by the expert.
\end{abstract}

Keywords: edamame, grading, quality parameter, expert system.

\section{Introduction}

Edamame (pronounced ay-dah-MAH-may) is the Japanese term for green vegetable soybeans [1]. Edamame is a specialty soybean (Glycine $\max$ (L.) Merr.) harvested as a vegetable [2]. Edamame is a kind of soybean that has a larger size of bean pods than traditional varieties [3]. Edamame beans are harvested before full maturity when bean pods are green and just before turning to yellow color. Most cultivated varieties in the world are of Japanese origin [4]. Edamame generally sold in the pods as fresh or frozen beans. For consumption, edamame is boiled with or without pods, is consumed as snacks, soups, salads, or vegetable dishes [1], [5], [6], [7].

Edamame is a popular crop that is widely consumed worldwide [8]. The seeds of edamame are characterized by high nutritional and medicinal value [2]. Edamame is a valuable food for vegetarians and vegans due to its high nutritional value [9]. Edamame beans are about $40 \%$ protein and provide several essential amino acids. They are a good source of Vitamin C, Vitamin K, iron, and fiber [10]. Vegetable soybeans are also used in the preparation of innovative products such as green milk, green tofu, and green noodles [11]. Edamame also has the potential for cancer prevention and suppression due to its high genistein content [12]. Clinical studies show that isoflavones in soybean proteins have a positive influence on blood substances and reduce the risk of cardiovascular diseases [6]. 
Quality components of edamame divided into two categories, including morphology quality and chemical composition. Morphology quality describes pod size, pod color, pubescent color, and the ratio of 2-3 seeds per pod. As for the chemical composition includes eating quality and nutrients [13]. In Iwate Prefecture, edamame divided into two grades, including grade A and grade B. Grade A edamame must have 90 percent or more pods with two or three seeds. The pods must be perfectly shaped, completely green, and show no injury or spotting. Grade B edamame must have 90 percent or more pods with two or three seeds but can be lighter green, and a few pods can be slightly spotted, injured, malformed, short, or have small seeds. In both grades, pods cannot be overly mature, diseased, insect-damaged, one-seeded, malformed, yellowed, split, spotted, or unripe [14].

In Indonesia, edamame divided into three grades, including Standard Quality (SQ), Second Grade (SG), and Third Grade (TG). SQ is a high grade (first quality), commonly used for the export market. The second quality or SG can become an export commodity depending on consumer demand. Meanwhile, the third quality or TG is an edamame commodity for the local market. The criteria for each level of quality based on the number of pods, appearance, pod color, and mechanical damage [15].

Edamame quality assessment process done by observing the physical characteristics of edamame based on predetermined criteria. However, this quality assessment process is not an easy job. With the criteria for determining the quality of edamame, which is quite numerous and varied, accurately, the process of assessing the quality of edamame based on its grade classification becomes very complicated.

However, an application system that can determine the quality of edamame is needed so that it can produce the right conclusions. The application system is an expert. The expert system is a computer system that emulates the decision-making ability of a human expert, which aims to solve complex problems by reasoning knowledge [16]. It is also known as an intelligent system or knowledge-based system [17]. It encapsulates specialist knowledge of a particular domain of expertise and can make intelligent decisions. It has a knowledge base and a set of rules that infer new facts from the knowledge. It based on expert knowledge to emulate human expertise in any specific field. Non-expert users, seeking advice in the field, question the system to get an expert's knowledge [18].

The objective of this study was to develop a methodology for building expert systems that can be used to determine edamame grade accurately. Users can consult directly through this expert system application as if dealing directly with an expert in the field of edamame grading. Expert system design using the forward chaining method. Forward chaining is the process of constructing a solution working from initial information. When forward chaining, the inference engine determines the best solution to the problem starting from the initial information and building toward the solution working forward [17].

\section{Research Method}

The material used was edamame pods (Glycine $\max$ (L.) Merr.) from edamame producers in Jember Regency. Edamame pods will be used for the verification process of the edamame grading expert system. The equipment used for the design of the edamame grading expert system are Windows 7, 64-bit Operating System, Visual Basic 6.0, dan Microsoft Office Access 2010.

Design of the expert system for edamame grading using the forward chaining method. Forward chaining is a method of matching facts or statements starting from the left side ('If first'), so reasoning starts from the facts first, then the truth of the hypothesis [19]. Figure 1 is a diagram of the forward chaining method used in an expert system. 


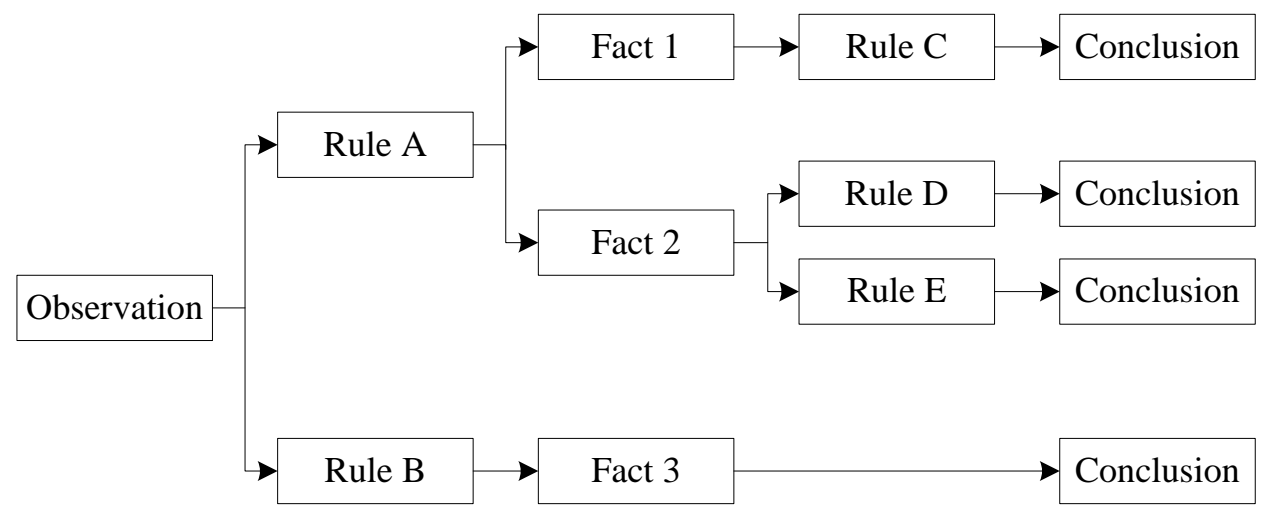

Figure 1

Forward chaining method

The expert system design for edamame grading is carried out in a structured and systematic manner as shown in Figure 2. Flow diagram of this research can be explained as follows:

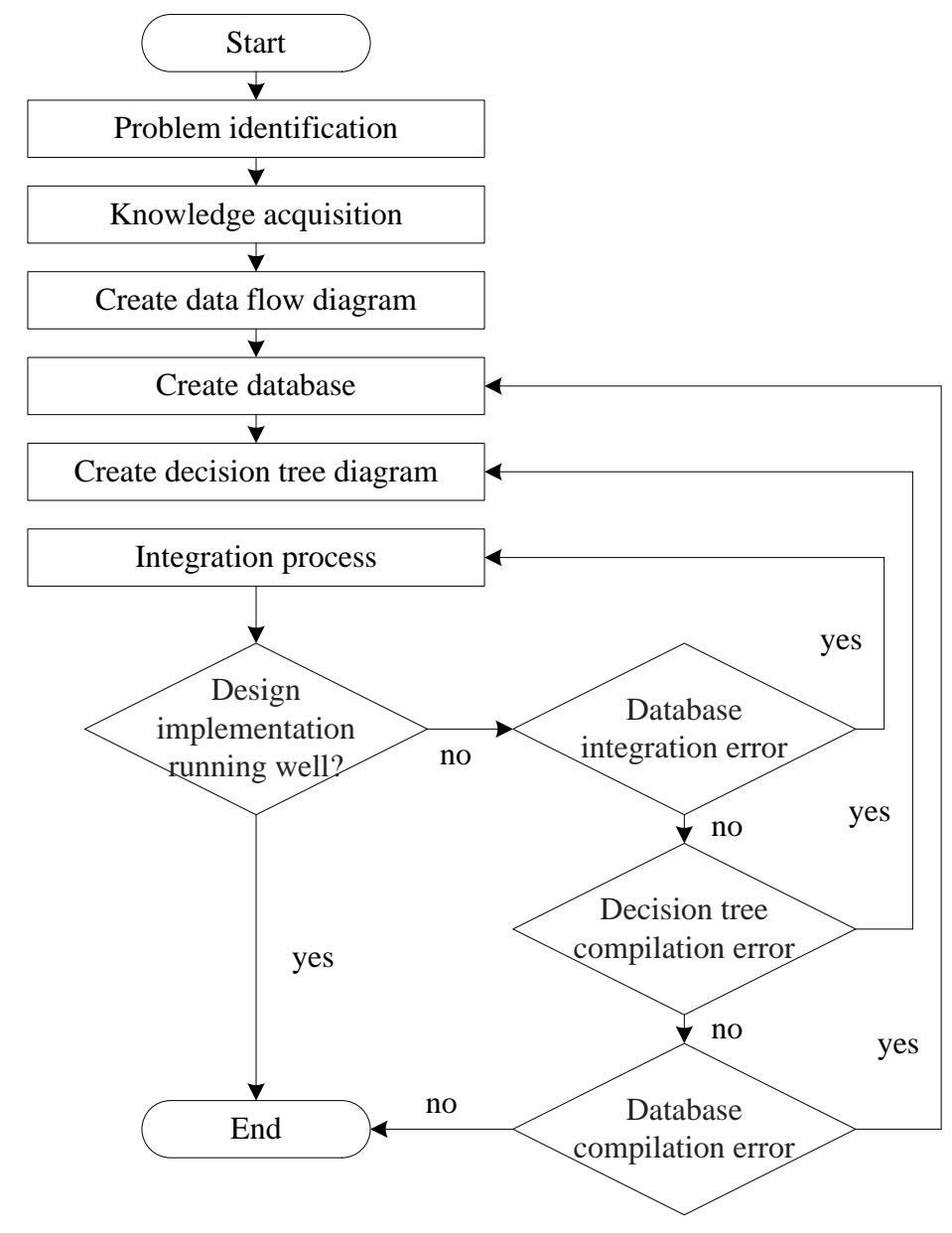

Figure 2

Research flow diagram 


\subsection{Problem identification}

Problem identification is the stage of finding and determining the existing problems so that the research objectives can be formulated clearly. The problem faced is the complexity of determining the edamame quality grade caused by the many criteria used.

\subsection{Knowledge acquisition}

Knowledge acquisition is the process of transferring expertise in solving problems from a particular source of knowledge into a program [20]. Sources of knowledge were obtained through literature study and expert knowledge. Experts chosen for knowledge acquisition are experts who came from PT. Mitratani 27 Jember, a company that exports edamame. The knowledge acquisition facility is used as a tool to obtain knowledge, facts, and rules used in the expert system.

\subsection{Building Data Flow Diagram}

A Data Flow Diagram (DFD) is a graphical representation of the "flow" of data through an information system, modeling its process aspects. Often it is a preliminary step used to create an overview of the system that can elaborate later. DFDs can also be used for the visualization of data processing (structured design) and show what kind of information will be input to and output from the system, where the data will come from and go to, and where the data will be stored [21].

The Level 0 DFD shows the simple model of the system, as shown on the DFD flow chart Figure 3. This context-level DFD is next "exploded" to produce a Level 1 DFD that shows some of the detail of the system being modeled, as shown on the DFD flow chart Figure 4.

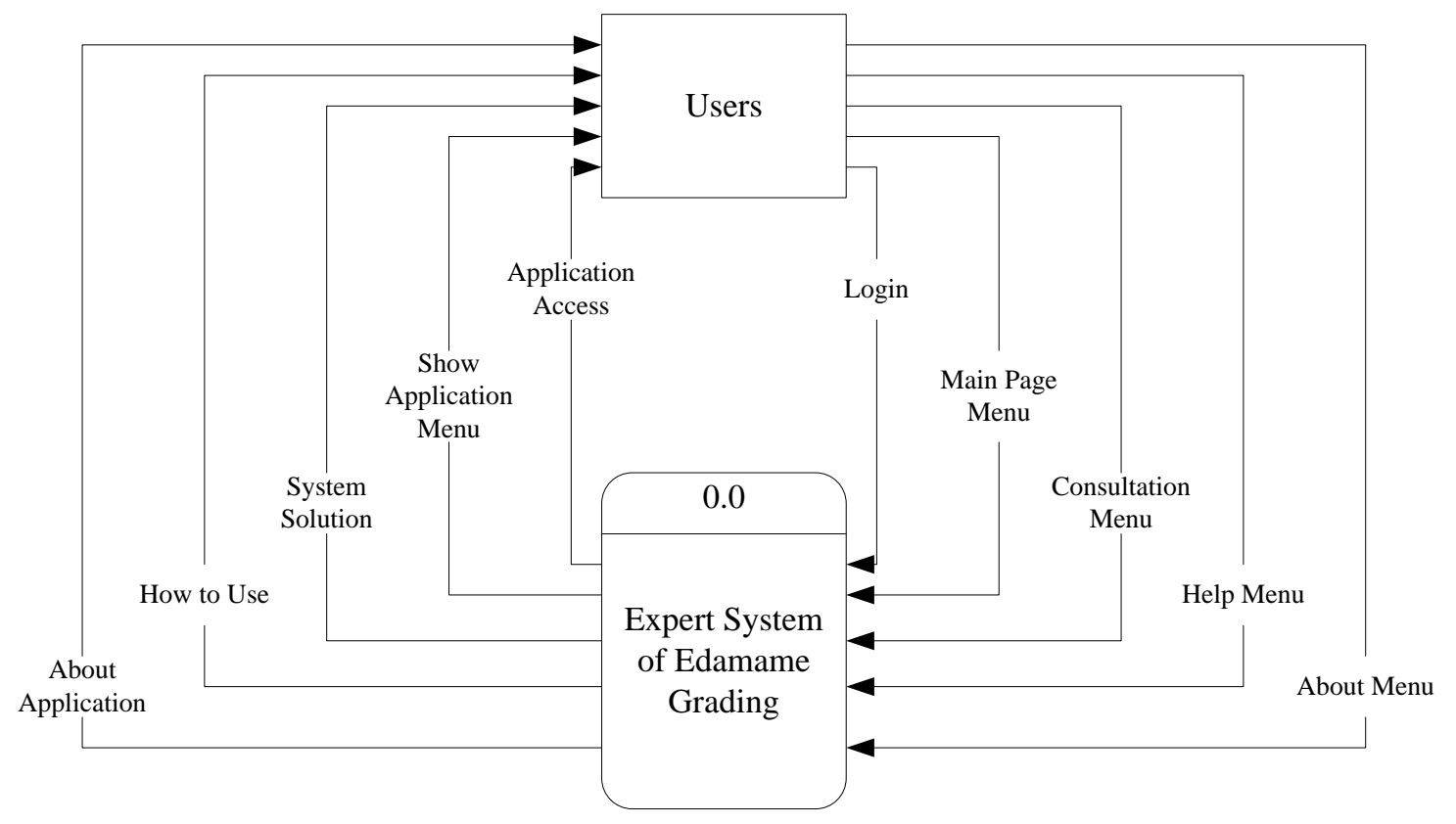

Figure 3

The level 0 DFD

Edamame grade is determined based on twelve parameters, including pests and diseases, shape, number of pods per 500 grams, mechanical damage, pod fiber, standard pods, appearance, pod length, pod thickness, pod color, cleanliness, tolerance to reject / 500 gram. The validation testing of edamame grade determination includes three grades, namely quality standard (SQ), second grade (SG), and third grade (TG). This is explained in DFD level 1 in Figure 4. 


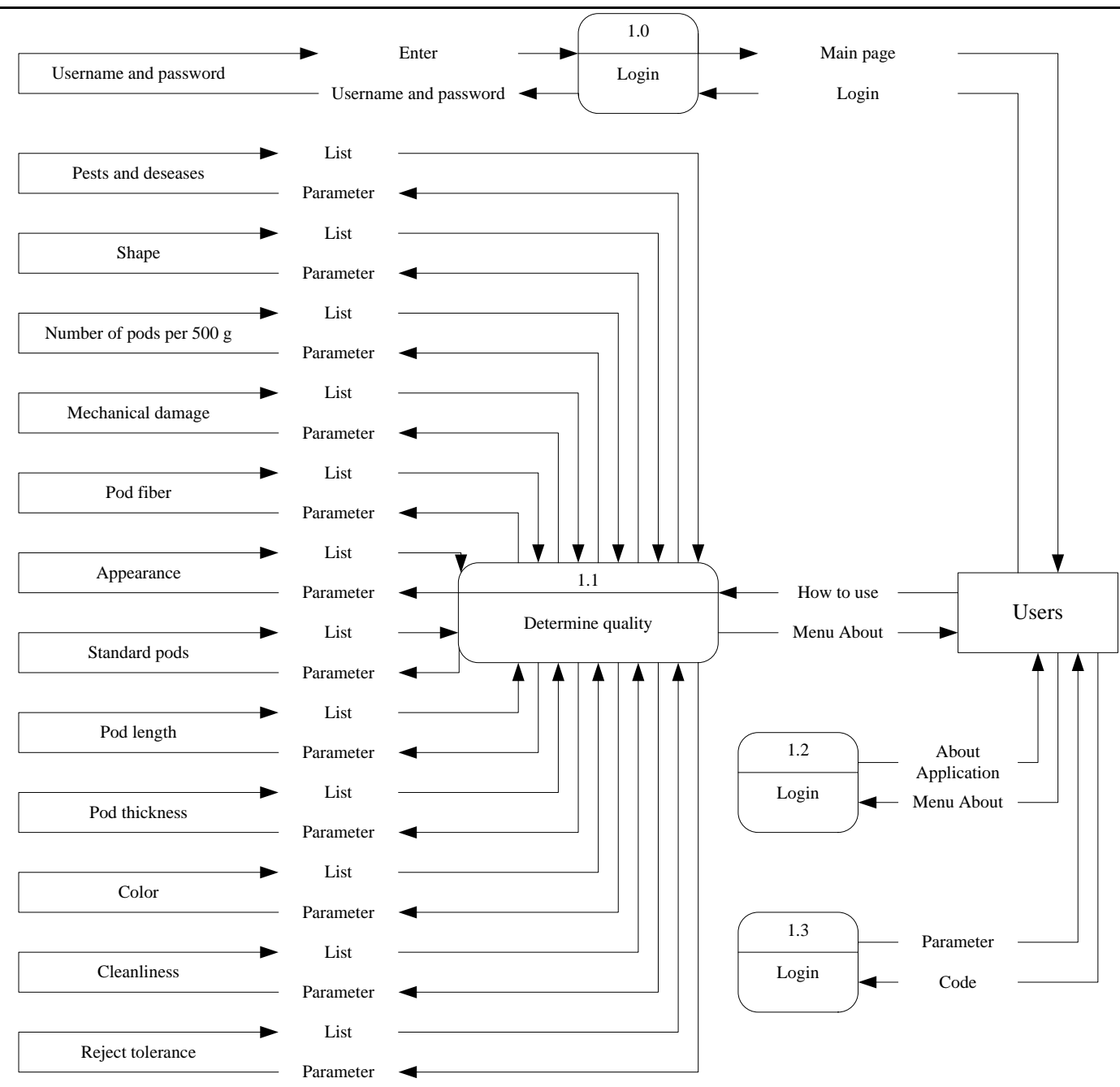

Figure 4

The level 1 DFD

\subsection{Compile the Database}

The database is compiled based on knowledge and information from experts in the grading process. Data processed in the database is data that is needed in user consultation with expert systems. The data compiled are edamame quality and grade parameters, including 12 parameters. The explanation of the relationship of each parameter is illustrated in an expert system database relationship diagram, as shown in Figure 5. Each edamame parameter relates one to one with the quality parameter.

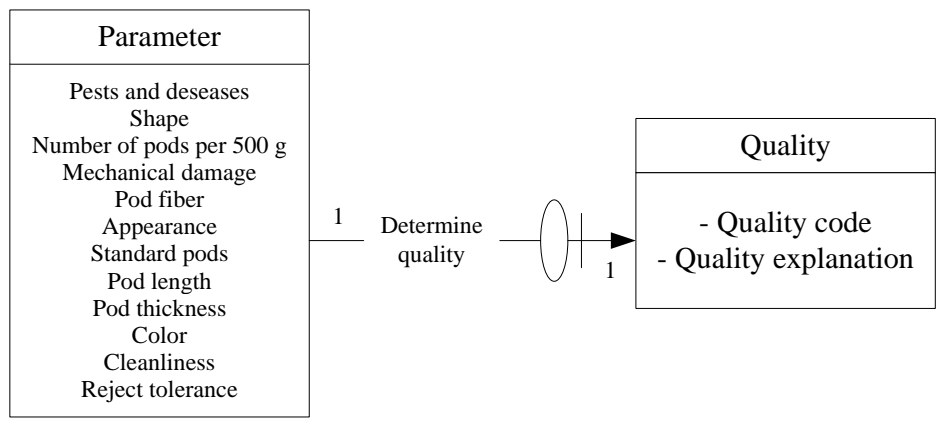

Figure 5

Expert system database relations diagram 


\subsection{Building a Decision Tree Diagram}

The acquired knowledge is then created inference networks or decision trees. Inference networks contain factors for making rules. The decision tree includes nodes and tree branches that can be traced based on the factor conditions at the initial node to the final node as a decision [22].

The decision tree is used to get answers to questions raised by the expert system so that a solution is obtained from user consultation with the expert system. Building a decision tree in an expert system for edamame grading is divided by each edamame quality or grade to facilitate the analysis to be carried out by the user. Quality or grade that is used as an analysis of the expert system in the edamame grading process includes standard quality grade (SQ), second grade (SG), and third grade (TG).

The decision tree is the basis and the main rules of the expert system decision making flow that is built. In the built system, the decision tree determines the order of the parameters determining the grade, based on the rules adopted by the experts intended to produce a solution. The decision tree for grade determination at the edamame grading stage is done by entering the determinants of the edamame grade, to produce a grade.

Table 1

Edamame grade parameter

\begin{tabular}{|c|c|c|}
\hline No & Kode & Aturan \\
\hline 1 & Q & Determine quality \\
\hline 2 & A1 & Pests and diseases: not indicated pests and diseases \\
\hline 3 & A2 & $\begin{array}{l}\text { Pests and diseases: may indicate pests and diseases max } 3 \mathrm{~mm} \text { (spots and rust on edamame } \\
\text { pods) }\end{array}$ \\
\hline 4 & B1 & Shape: pods 2 and 3 \\
\hline 5 & B2 & Shape: pods 3 empty1 \\
\hline 6 & $\mathrm{C} 1$ & Number of pods per 500 gr: 165 (pods) \\
\hline 7 & $\mathrm{C} 2$ & Number of pods per 500 gr: 175 (pods) \\
\hline 8 & $\mathrm{C} 3$ & Number of pods per 500 gr: 190 (pods) \\
\hline 9 & D1 & Mechanical damage: edamame not broken \\
\hline 10 & E1 & Pod fiber: peel fiber maximum 1 \\
\hline 11 & $\mathrm{~F} 1$ & Appearance: not too old (yellow) and young pods \\
\hline 12 & G1 & Pod standard: no pods seed one and pods seeds two empty one \\
\hline 13 & H1 & Pod length: $\min 2,5 \mathrm{~cm}$ \\
\hline 14 & I1 & Pod thickness: $\min 0,7 \mathrm{~mm}$ \\
\hline 15 & $\mathrm{~J} 1$ & Color: green uniform \\
\hline 16 & $\mathrm{~K} 1$ & Cleanliness: there are no foreign objects \\
\hline 17 & L1 & Reject tolerance per 500 gr: $\max 5 \%$ \\
\hline 18 & $\mathrm{~L} 2$ & Reject tolerance per 500 gr: $\max 10 \%$ \\
\hline 19 & SQ & $\begin{array}{l}\text { (Not indicated by pests and diseases), (pods } 2 \text { and } 3),(165),(\text { none }),(\text { fiber peeled } \max 1 \\
\text { seed), (pods not too old and young), (no seed pods } 1 \text { and no pods seeds } 2 \text { flak } 1),(\text { min } \\
2.5 \mathrm{~cm}),(0.7 \mathrm{~mm}),(\text { uniform green), (no foreign matter), (max } 5 \%) \text {. }\end{array}$ \\
\hline 20 & SG & $\begin{array}{l}\text { (Not indicated by pests and diseases / May indicate pests and diseases } \max 3 \mathrm{~mm}),(\text { pods } 2 \\
\text { and } 3 \text { / pods } 3 \text { flak } 1),(175),(\text { edamame not broken), (chipped fiber } \max 1 \mathrm{seed}),(\text { pods not } \\
\text { too old and young), (no } 1 \text { seed pods and no } 2 \text { pod seeds } 1 \text { pods), (min } 2.5 \mathrm{~cm}, 0.7 \mathrm{~mm} \text {, } \\
\text { (uniform green), (no foreign matter), (max } 5 \%) \text {. }\end{array}$ \\
\hline 21 & TG & $\begin{array}{l}\text { (Not indicated by pests and diseases / May indicate pests and diseases } \max 3 \mathrm{~mm}),(\text { pods } 2 \\
\text { and } 3 \text { / pods } 3 \text { flak } 1),(190),(\text { edamame not broken), (chipped fiber } \max 1 \mathrm{seed}),(\text { pods not } \\
\text { too old and young), (no } 1 \text { seed pods and no } 2 \text { pod seeds } 1 \text { pods), (min } 2.5 \mathrm{~cm}, 0.7 \mathrm{~mm}), \\
\text { (uniform green), (no foreign matter), }(\max 10 \%) \text {. }\end{array}$ \\
\hline
\end{tabular}




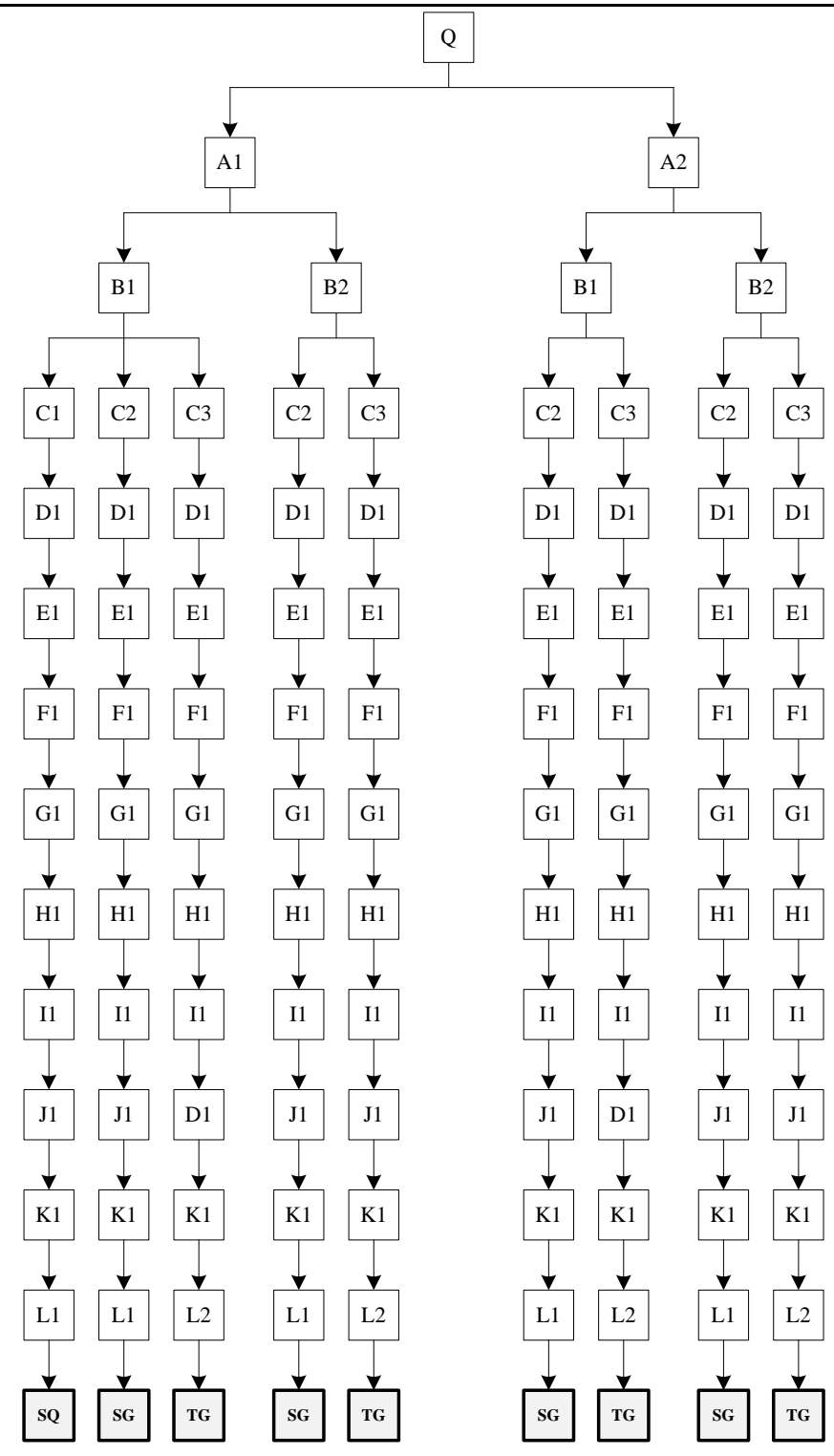

Figure 6

The decision tree diagram

\section{Results and Discussion}

\subsection{Expert System Verification}

Expert System verification as the process of checking an Expert System against the specifications generated by its formalizable requirements [23]. In the verification process, an evaluation carried out on the computerized process, logical work, and substance elements accommodated by the model [24]. Verification aims to ensure that the model of the expert system can be run well [25].

The checking process intends to test the expert system interface design as a specification, to avoid errors that occur in writing programs, database errors, errors when programs run, and errors in logic. Verification testing carried out on the edamame grading expert system, the relationship between the user and the consultation media. Related sections include login page, main page, consultation page, and help page and about page. The results of the expert system verification for edamame grading can be seen in Table 2. 
Table 2

Expert system verification

\begin{tabular}{|c|c|c|c|}
\hline Description & Input & Achievement Indicator & Result \\
\hline Login & $\begin{array}{l}\text { Username: } 001 \text { or } 002 \\
\text { Password: admin or user }\end{array}$ & $\begin{array}{l}\text { Users can sign in to the main } \\
\text { menu }\end{array}$ & Good \\
\hline Main page & $\begin{array}{l}\text { Click Consultation page } \\
\text { Click Help page } \\
\text { Click About page } \\
\text { Click exit }\end{array}$ & $\begin{array}{l}\text { Bring up the edamame grading } \\
\text { consultation page } \\
\text { Bring up a page on how to use the } \\
\text { expert system application } \\
\text { Bring up the purpose, benefits } \\
\text { and how to use it } \\
\text { Exit to the opening page }\end{array}$ & Good \\
\hline Consultation page & $\begin{array}{l}\text { Pests and diseases, shape, number } \\
\text { of pods per } 500 \text { grams, mechanical } \\
\text { damage, pod fiber, standard pods, } \\
\text { appearance, pod length, pod } \\
\text { thickness, pod color, cleanliness, } \\
\text { tolerance to reject per } 500 \text { gram } \\
\text { Click enter } \\
\text { Click refresh } \\
\text { Click grade } \\
\text { Click explanation } \\
\text { Click picture } \\
\text { Click exit }\end{array}$ & $\begin{array}{l}\text { Enter data from quality } \\
\text { parameters into the text field } \\
\text { Clear out the contents of quality } \\
\text { text fields } \\
\text { Bring up the grade } \\
\text { Bring upgrade detail } \\
\text { Bring up edamame picture } \\
\text { Exit to the opening page }\end{array}$ & Good \\
\hline Help page & $\begin{array}{l}\text { Click help page } \\
\text { Click end }\end{array}$ & $\begin{array}{l}\text { Users can learn how to use the } \\
\text { edamame grading application } \\
\text { Exit to the opening page }\end{array}$ & Good \\
\hline About page & Click on the about page & $\begin{array}{l}\text { Users can find out the purpose } \\
\text { and benefits of edamame grading } \\
\text { expert system } \\
\text { Exit to the opening page }\end{array}$ & Good \\
\hline
\end{tabular}

Login Page

Verification of login page testing aims to find out whether the program is running by the intended use. The purpose of using the login menu is that users can enter the main page of the system using a username and password by the database. The test results are said to be good if the user can enter the main system page by filling in the username and password provided.

\section{Main Page}

On the main page contains four menus, namely the consultation menu, the help menu, the about the menu, and the exit menu. Testing on the main page aims to find out that each menu is functioning properly. If the user presses the consultation button, then the user will switch to the consultation page. If the user presses the help button, then the user will switch to the help page that contains how to use the expert system from the login page, the main page, and the consultation page. If the user pressed about the button, then the user will switch to the about page that contains the goals and benefits of the expert grading system edamame.

Furthermore, if the user presses the exit button, then the user will exit the expert system application. Verification test results show that all the menu buttons on the main page are functioning properly. The user can choose the consultation page, help page, about page, and exit page. 
Consultation Page

Verification testing on the consultation page aims to know the accuracy of the consultation page. In the consultation page, the consultation carried out on three frames, including parameter frames, grade frames, and grade explanation frames. The frame parameter is composed of the edamame grade parameter column. Each column connected to the database. The database contains edamame quality parameters based on data obtained from knowledge acquisition so that when the application is running, the data from the database will be displayed on the combo box based on the command according to coding. How to use columns in the edamame grade parameter frame by clicking the combo box arrow image, then selecting the parameter list provided. The use of the edamame grade parameter column contains twelve parameters built using the combo box, so the user only has to choose the list provided.

Edamame grade determination is done by selecting data from each component parameter, then press 'enter' automatically the data set of the edamame grade parameter will fill the quality column on the top of the grade button. If a message appears 'data not found' then the data entered based on parameters is not appropriate or not available in the database.

In the frame, grade contains one use button and one blank column. The button is used to bring up the grade based on data from the parameters selected in the frame parameter. In the explanation, the frame contains a usage button and an empty column. Verification test results show that all the menu buttons on the consultation page are functioning properly. The user can do consultations regarding edamame grade.

\section{Help Page}

Verification testing on the help page aims to determine the accuracy of the help page. The help page functions to find out how to use the expert system applications for edamame grading to make it easier for users to apply the expert system applications for edamame grading. The help page contains an explanation of how to use starting from the login, main page to the consultation page. Verification test results show that all the menu buttons on the help page are functioning properly. The user can enter the help page to find out how to use the expert system applications for edamame grading.

\section{About Page}

Verification testing on the about page aims to determine the level of accuracy of the about page. About page, functions to find a general explanation about expert system application, including the purpose and benefits of the edamame grading expert system that built.

Verification test results show that all the menu buttons on the about page are functioning properly. The user can enter the about page to find out the general explanation of the grading expert system, as well as the purpose and benefits of making a grading expert system edamame.

\subsection{Expert System Validation}

Expert system validation is a determination of the correctness of an expert system concerning the user needs and requirements [23]. The validation process intended to improve the level of confidence based on assumed conditions, the model can represent the actual system [24], [25], [26]. Expert system validation in this research uses event validity. The "events" of occurrences of the simulation model are compared to those of the real system to determine if they are similar [27]. The validation testing phase of the edamame grade determination intended to find out the program that made is running following the Standard Operating Procedure (SOP) on determining the quality of edamame based on a decision tree as a rule for decision making. 
At the system validation stage, an analysis of the expert system's output carried out by the decision of an expert (human expert). The validation of decision-making testing carried out on the determination of grade consisting of various edamame grade parameters including pests and diseases, shape, number of pods per 500 grams, mechanical damage, pod fiber, standard pods, appearance, pod length, thickness, pod color, cleanliness, tolerance rejected / 500 gram.

Table 3

Edamame grade parameter

\begin{tabular}{|c|c|c|c|}
\hline No & Grade & Parameter & Information \\
\hline \multirow[t]{12}{*}{1.} & $\begin{array}{l}\text { Standard } \\
\text { quality }\end{array}$ & Pests and diseases & Not indicated by pests and diseases \\
\hline & & Shape & Pods 2 and 3 \\
\hline & & Number of pods per 500 grams & 165 \\
\hline & & Mechanical damage & The pod is not broken \\
\hline & & Pod fiber & Peeled fiber max 1 seeds \\
\hline & & Appearance & $\begin{array}{l}\text { The pods are not too old (yellow) and the } \\
\text { pods are not too young, }\end{array}$ \\
\hline & & Standard pods & There are no pods 1 and no pods 2 empty 1 \\
\hline & & Pod length & Min $2.5 \mathrm{~cm}$ \\
\hline & & Thickness & $0.7 \mathrm{~mm}$ \\
\hline & & Pod color & Green uniform \\
\hline & & Cleanliness & There are no foreign objects, \\
\hline & & Tolerance rejected per 500 gram & Max 5\%. \\
\hline \multirow[t]{12}{*}{2} & $\begin{array}{l}\text { Second } \\
\text { grade }\end{array}$ & Pests and diseases & $\begin{array}{l}\text { Not indicated by pests and diseases / May } \\
\text { indicate pests and diseases } \max 3 \mathrm{~mm}\end{array}$ \\
\hline & & Shape & Pods 2 dan 3 / pods 3 empty 1 \\
\hline & & Number of pods per 500 grams & 175 \\
\hline & & Mechanical damage & The pod is not broken \\
\hline & & Pod fiber & Peeled fiber max 1 seeds \\
\hline & & Appearance & $\begin{array}{l}\text { The pods are not too old (yellow), and the } \\
\text { pods are not too young, }\end{array}$ \\
\hline & & Standard pods & There are no pods 1 and no pods 2 empty 1 \\
\hline & & Pod length & Min $2.5 \mathrm{~cm}$ \\
\hline & & Thickness & $0.7 \mathrm{~mm}$ \\
\hline & & Pod color & Green uniform \\
\hline & & Cleanliness & There are no foreign objects, \\
\hline & & Tolerance rejected per 500 gram & $\operatorname{Max} 5 \%$ \\
\hline \multirow[t]{12}{*}{3} & $\begin{array}{l}\text { Third } \\
\text { grade }\end{array}$ & Pests and diseases & $\begin{array}{l}\text { Not indicated by pests and diseases / May } \\
\text { indicate pests and diseases max } 3 \mathrm{~mm}\end{array}$ \\
\hline & & Shape & Pods 2 dan 3 / pods 3 empty 1 \\
\hline & & Number of pods per 500 grams & 190 \\
\hline & & Mechanical damage & The pod is not broken \\
\hline & & Pod fiber & Peeled fiber max 1 seeds \\
\hline & & Appearance & There are no pods 1 and no pods 2 empty 1 \\
\hline & & Standard pods & There are no pods 1 and no pods 2 empty 1 \\
\hline & & Pod length & Min $2.5 \mathrm{~cm}$ \\
\hline & & Thickness & $0.7 \mathrm{~mm}$ \\
\hline & & Pod color & Green uniform \\
\hline & & Cleanliness & There are no foreign objects, \\
\hline & & Tolerance rejected per 500 gram & $\operatorname{Max} 10 \%$ \\
\hline
\end{tabular}


Table 4

Rules for determining quality grade based on parameters

\begin{tabular}{|c|c|c|c|c|c|c|c|c|c|c|c|c|c|c|c|c|c|c|c|}
\hline \multirow{2}{*}{ No } & \multicolumn{17}{|c|}{ Indication } & \multirow{2}{*}{ Quality } & \multirow{2}{*}{$\begin{array}{l}\text { Appropriate } \\
\text { or Not } \\
\text { Appropriate }\end{array}$} \\
\hline & A1 & A 2 & B1 & B2 & $\mathrm{C} 1$ & $\mathrm{C} 2$ & $\mathrm{C} 3$ & D1 & E1 & $\mathrm{F} 1$ & G1 & H1 & I1 & $\mathrm{J} 1$ & K1 & L1 & L2 & & \\
\hline 1 & $\sqrt{ }$ & - & $\sqrt{ }$ & - & $\sqrt{ }$ & - & - & $\sqrt{ }$ & $\sqrt{ }$ & $\sqrt{ }$ & $\sqrt{ }$ & $\sqrt{ }$ & $\sqrt{ }$ & $\sqrt{ }$ & $\sqrt{ }$ & $\sqrt{ }$ & - & SQ & Appropriate \\
\hline \multirow{4}{*}{2} & $\sqrt{ }$ & - & $\sqrt{ }$ & - & - & $\sqrt{ }$ & - & $\sqrt{ }$ & $\sqrt{ }$ & $\sqrt{ }$ & $\sqrt{ }$ & $\sqrt{ }$ & $\sqrt{ }$ & $\sqrt{ }$ & $\sqrt{ }$ & $\sqrt{ }$ & - & \multirow{4}{*}{ SG } & \multirow{4}{*}{ Appropriate } \\
\hline & $\sqrt{ }$ & - & - & $\sqrt{ }$ & - & $\sqrt{ }$ & - & $\sqrt{ }$ & $\sqrt{ }$ & $\sqrt{ }$ & $\sqrt{ }$ & $\sqrt{ }$ & $\sqrt{ }$ & $\sqrt{ }$ & $\sqrt{ }$ & $\sqrt{ }$ & - & & \\
\hline & - & $\sqrt{ }$ & $\sqrt{ }$ & - & - & $\sqrt{ }$ & - & $\sqrt{ }$ & $\sqrt{ }$ & $\sqrt{ }$ & $\sqrt{ }$ & $\sqrt{ }$ & $\sqrt{ }$ & $\sqrt{ }$ & $\sqrt{ }$ & $\sqrt{ }$ & - & & \\
\hline & - & $\sqrt{ }$ & - & $\sqrt{ }$ & - & $\sqrt{ }$ & - & $\sqrt{ }$ & $\sqrt{ }$ & $\sqrt{ }$ & $\sqrt{ }$ & $\sqrt{ }$ & $\sqrt{ }$ & $\sqrt{ }$ & $\sqrt{ }$ & $\sqrt{ }$ & - & & \\
\hline \multirow{4}{*}{3} & $\sqrt{ }$ & - & $\sqrt{ }$ & - & - & - & $\sqrt{ }$ & $\sqrt{ }$ & $\sqrt{ }$ & $\sqrt{ }$ & $\sqrt{ }$ & $\sqrt{ }$ & $\sqrt{ }$ & $\sqrt{ }$ & $\sqrt{ }$ & - & $\sqrt{ }$ & \multirow{4}{*}{ TG } & \multirow{4}{*}{ Appropriate } \\
\hline & $\sqrt{ }$ & - & - & $\sqrt{ }$ & - & - & $\sqrt{ }$ & $\sqrt{ }$ & $\sqrt{ }$ & $\sqrt{ }$ & $\sqrt{ }$ & $\sqrt{ }$ & $\sqrt{ }$ & $\sqrt{ }$ & $\sqrt{ }$ & - & $\sqrt{ }$ & & \\
\hline & - & $\sqrt{ }$ & $\sqrt{ }$ & - & - & - & $\sqrt{ }$ & $\sqrt{ }$ & $\sqrt{ }$ & $\sqrt{ }$ & $\sqrt{ }$ & $\sqrt{ }$ & $\sqrt{ }$ & $\sqrt{ }$ & $\sqrt{ }$ & - & $\sqrt{ }$ & & \\
\hline & - & $\sqrt{ }$ & - & $\sqrt{ }$ & - & - & $\sqrt{ }$ & $\sqrt{ }$ & $\sqrt{ }$ & $\sqrt{ }$ & $\sqrt{ }$ & $\sqrt{ }$ & $\sqrt{ }$ & $\sqrt{ }$ & $\sqrt{ }$ & - & $\sqrt{ }$ & & \\
\hline
\end{tabular}

The expert system output is to produce edamame quality grade classified according to the rules, as shown in Table 4 . The basic rules used are decision tree diagrams designed based on expert knowledge, as shown in Figure 6.

The validation results show that the edamame quality output produced by the expert system is the same as the expert solution, meaning that the expert system's output data is incompatible with the results of the decision given by the expert. In testing the validation of determining the quality is appropriate. Validation results can be seen in Table 5 .

Table 5

The results of the determination of edamame grade

\begin{tabular}{llll}
\hline No & System Output & Expert Solution & Appropriate/Not \\
\hline 1 & Standard quality & Standard quality & Appropriate \\
2 & Second grade & Second grade & Appropriate \\
3 & Third grade & Third grade & Appropriate \\
\hline
\end{tabular}

\section{Conclusion}

The results of the verification and validation of the edamame grading expert system show that the expert system has produced satisfactory outcomes. Expert system output is compatible with the solution provided by the expert. Thus, the expert system can be used to determine the quality of edamame accurately.

\section{References}

[1] Shurtleff W \& Aoyagi A. (2009). History of edamame, green vegetable soybeans, and vegetable-type soybeans (1275-2009): Extensively annotated, Bibliography and sourcebook. Soy info Center, Lafayette, CA, USA.

[2] Konovsky J, Lumpkin T A, \& MeClary D. (1994). Edamame: the vegetable soybean. In Understanding the Japanese Food and Agrimarket: a multifaceted opportunity: 173-181. Binghamton: Haworth Press.

[3] Saldivar X, Eang Y J, Chen P \& Hou A. (2011). Changes in chemical composition during soybean seed development. Food Chemistry. 124(4): 1369-1375. DOI: 10.1016/j.foodchem.2010.07.091.

[4] Zeipina S, Alsina I \& Lepse L. (2017). Insight in edamame yield and quality parameters: A review. Research for rural development. 2 . DOI:10.22616/rrd.23.2017.047

[5] Johnson D, Wang S \& Suzuki A. (1999). Edamame: a vegetable soybean for Colorado. In J. Janick (Eds.), Perspectives on new crops and new uses: 385-387. Alexandria: ASHS Press. 
[6] Mentreddy S R, Mohamed A I, Joshee N \& Yaav A K. (2002). Edamame: A nutritious vegetable crop. Trends in new crops and new uses: 432-438. Alexandria: ASHS Press.

[7] Stevenson D G, Jane J \& Inglett G E. (2007). Structures and physicochemical properties of starch from immature seeds of soybean varieties (Glycine $\max (\mathrm{L}$.$) Merr.) Exhibiting normal, low-linolenic,$ or low-saturated fatty acid oil profiles at maturity. Carbohydrate Polymers. 70 (2): 149-159. DOI: 10.1016/j. carbpol.2007.03.016.

[8] Song J, Liu C, Li D \& Gu Z. (2013). Evaluation of sugar, free amino acid, and organic acid compositions of different varieties of vegetable soybean (Glycine max (L.) Merr). Industrial Crops and Products. 50: 743-749. DOI: 10.1016/j.indcrop.2013.08.064.

[9] Miles C A, Lumpkin T A \& Zenz L. (2000). Edamame. Farming west of the cascades. Washington State University, Washington, DC, USA.

[10] Worwood D. (2014). Edamame in the Garden. USU Extension Educator.

[11] Basavaraja G T, Naidu G K \& Salimath P M. (2005). Evaluation of vegetable soybean genotypes for yield and component traits. Karnataka Journal of Agricultural Science. 18(1): 27-31.

[12] Huang M, Wang Q, Zhang M \& Zhu Q. (2014). Prediction of color and moisture content for vegetable soybean during drying using hyperspectral imaging technology. Journal of Food Engineering. 128, 24-30. DOI: 10.1016/j.jfoodeng.2013.12.008.

[13] Shanmgasundaram S. (1991). Vegetable soybean: research needs for production and quality improvement. In: Proceedings of a workshop held at Kenting, Taiwan. Asian Vegetable Research and Development Center: 150.

[14] IDA. (1990). Iwate- ken Seikabutsu To Shukka Kikaku Shido Hikkei. Iwate- ken Department of Agriculture, Morioka.

[15] Yuliana A E, Iswono S \& Suhartono (2013). The controlling of the production process of frozen edamame soybeans in PT. Mitratani Dua Tujuh Jember. The University of Jember.

[16] Tan H. (2017). A brief history and technical review of the expert system research. ICAMMT. IOP Conf. Series: Materials Science and Engineering 242 (2017) 012111 DOI:10.1088/1757899X/242/1/012111.

[17] DeTore A W. (1989). An introduction to expert systems. Journal of insurance Medicine, 21(4): 233236.

[18] Sadiku M N O, Wang Y, \& Cui S M (2018). Expert Systems: A Primer. International Journals of Advanced Research in Computer Science and Software Engineering ISSN: 2277-128X. 8 (6).

[19] Marimin (2005). Theory and application of expert systems in managerial technology. Bogor: IPB Press.

[20] Buchanan B G \& Shortliffe E H (1984). Ruled-Based Expert System: The MYCIN Experiment of The Stanford Heuristic Programming Project. Addison Wesley Publishing Co.

[21] Scheel H V, Rosing M V, Hove M, Foncesa M \& Foldager U. (2015). The Complete Business Process Handbook Body of Knowledge from Process Modeling to BPM.1.

[22] Hart A. (1986). Knowledge Acquisition for Expert System. McGraw-Hill Book Co. New York.

[23] Meseguer P. (1992). Towards a Conceptual Framework for Expert System Validation. Journal AI Communications. 5 (3): 119-135.

[24] Eriyatno (1999). Ilmu Sistem: Meningkatkan Mutu dan Efektivitas Manajemen. 1st Ed. IPB Press, Bogor.

[25] Law A M \& Kelton D W. (2000). Simulation modeling and analysis. McGraw-Hill.

[26] Udayana I G B. (2015). Model Development Industrial Cluster Coffee Arabica in The District Bangli, Province of Bali. International Journal on Advanced Science, Engineering and Information Technology, 5(4): 294-297.

[27] Sargent R G. (2010). Verification and Validation of Simulation Models. Proceedings of the 2010 Winter Simulation Conference. B. Johansson, S. Jain, J. Montoya-Torres, J. Hugan, and E. Yücesan, eds. 